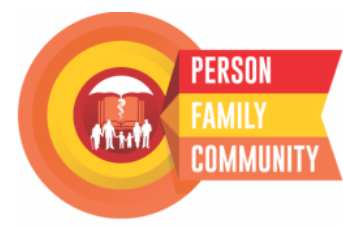

Journal Homepage:

https://jurnal.ugm.ac.id/rpcpe
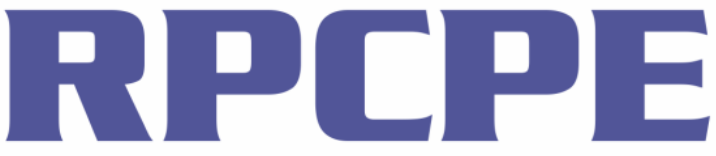

ISSN 2613-943X (print)

ISSN 2620-5572 (online)

Review of Primary Care Practice and Education (Kajian Praktik dan Pendidikan Layanan Primer)

\title{
Adaptation of Home Falls and Accidents Screening Tool (HOME FAST) as a Fall Risk Screening Tool for the Elderly in First Level Health Facilities at Purworejo Regency
}

Dewi Susilowardani ${ }^{1}$, Wahyudi Istiono ${ }^{2}$, Dewa Putu Pramantara ${ }^{3}$

\author{
${ }^{1}$ Primary Health Care Centre (Puskesmas) Loano; Indonesia \\ ${ }^{2}$ Department of Family and Community Medicine; Faculty of Medicine, Public Health and Nursing; Universitas Gadjah Mada; \\ Indonesia \\ ${ }^{3}$ Department of Internal Medicine; RSUP Dr. Sardjito; Indonesia
}

Corresponding Author:

Dewi Susilowardani: Primary Health Care Centre (Puskesmas) Loano, Jl. Magelang KM. 8 Purworejo, Pecitran, Maron, Loano, Kota Magelang, Central Java - 54181, Indonesia

E-mail: dewi susilowardani@yahoo.com

To cite this article:

Susilowardani D, Istiono W, Pramantara DP. Adaptation of home falls and accidents screening tool (HOME FAST) as a fall risk screening tool for the elderly in first level health facilities at Purworejo Regency. Rev Prim Care Prac and Educ. 2020; 3(2): 6-13.

\begin{abstract}
Background: The Home Falls and Accidents Screening Tool (HOME FAST) is used for early detection of unsafe environmental conditions at home and risk factors for falls in the elderly. However, in Indonesia there are no data on the adaptation of this instrument. Objective: To determine if the HOME FAST adaptation can be used as a screening tool for the risk of falling in the elderly in the First Level Health Facilities/Fasilitas Kesehatan Tingkat Pertama (FKTP) of Purworejo Regency. Methods: This research was a quantitative study with a cross-sectional design. Subjects were elderly with age over 65 years in the Puskesmas Loano working area that met the inclusion and exclusion criteria. Results: After the adaptation of the HOME FAST instrument was completed, a validity test was performed and a $r$ table result of 0.361 was obtained, indicating all questions were valid. Reliability testing using the Cronbach Alpha formula obtained 0.8461. Subjects were 300 respondents with a distribution of 135 men (45\%) and 165 women (55\%). The results of the bivariate analysis found three factors that were statistically significantly related, namely gender, age, and the total score of the HOME FAST adaptation instrument. Gender was statistically significantly correlated with a history of falls $p=0.045$ (95\% CI 2.14-2.56) with RP 1.57 while age was significant with $p=0.046$ with (95\% CI: 2.85-3.46), and the risk of unsafe total HOME FAST scoring with $p=0.024$. From the $2 \times 2$ table calculations, the sensitivity of the HOME FAST adaptation scoring method was low with $46 \%$ and the specificity of $67 \%$. Conclusion: The adaptation of HOME FAST has a sensitivity of $46 \%$ and a specificity of $67 \%$. The prevalence of adaptation results from HOME FAST risk of falling was $36.66 \%$, with the number of safe houses were 190 housing units and 110 unsafe houses.
\end{abstract}

Keywords: Falling in elderly, FKTP, HOME FAST, Indonesian risk screening for elderly falling

\section{INTRODUCTION}

More than one third of the elderly suffer a fall every year, and $20 \%$ to $30 \%$ have moderate to severe injuries such as hip fractures and head injuries that reduce their mobility and independence. Falling in the elderly who are 65 years or older can cause fatal and non-fatal trauma. The incidence of falls in China is 6-31\%, in Japan 20\%, and in Latin America $21.6 \%{ }^{1}$. The incidence of falls in Malaysia is reported to be $27 \%$ of the elderly who are living in the rural communities, and half of them will experience recurrent falls in the same year ${ }^{2}$. Indonesia's data of instability and fall incidents are still very limited. Handayani's research in the Geriatric Division of RSUPN Cipto Mangunkusumo Hospital found an instability incidence rate of $23.3 \%{ }^{3}$. Given the high proportion of falling that occurs at the homes of the elderly, home security intervention is the an essential consideration to create proper safeguards ${ }^{4}$.

The Home Falls and Accidents Screening Tool (HOME FAST) is used for early detection of unsafe homes and risk factors for falling in the elderly. A Malaysian study mentions that HOME FAST is feasible to be used to detect unsafe environments at home and risk of falling in older people in the context of Malaysia ${ }^{2}$.

Many $(32.72 \%)$ of the elderly in Central Java live in rural areas. The projected number of elderly people in Purworejo in 2017 was $120,384,000$ out of the total population of $714,564,000$ which represents $16.85 \%$ of the total population. With this large percentage of elderly people, the city of Purworejo is better known as the 'pension city'. Accordingly, with the large number of elderly people living in Loano, an elderly subdistrict in the area, it is important to obtain safe house criteria according to the characteristics of the population in the Purworejo District.

\section{RESEARCH METHODS}

This research was a quantitative observational study with a cross sectional design. In this research, the adaptation of 
HOME FAST was validated for use as a fall risk tool in elderly in Purworejo District first level health facility.

Subjects of this study were all elderly individuals aged 65 years or older who were from the elderly population in the work area of thePuskesmas Loano Purworejo. The sample selection in this study used stratified random sampling.

The inclusion criteria were: (1) Age 65 years or older who live in the area; (2) Able to share in communication; and (3) Willing to follow the research. Exclusion criteria were: Questionnaire data were incomplete.

This research consisted of two variables, namely the dependent variable (bound) and independent variable (free). The independent variable was the security of elderly who stay at home, while the dependent variable was the incidence of falling in the elderly during the last year.

Methods of data retrieval used interviews and observations with 2 sessions. First, the explanation sheet was given to prospective research subjects, then they completed the statement of willingness to be subjects of research, sociodemographic data, and finally, there were the subsequent interview meeting and observations based on patient identity questionnaire and HOME-FAST adaptation instrument. Questions and observations in the questionnaire were read by the data-takers, i.e. researchers and research assistants. The research assistants consisted of 6 people including 4 paramedics D3 midwifery and 2 D3 nursing staff. The research assistants involved in the research were properly briefed about the procedures of collecting data before the research started.

In this study, to assess the risk of falling elderly due to environmental factors, observations were made using the Home Falls and Accidents Screening Tool (HOME FAST $)^{6}$. The HOME FAST instrument was translated into

Bahasa Indonesia by the Translation Service Unit English Department of Faculty of Cultural Sciences Universitas Gadjah Mada then adapted using the Java language and tested for its validity and reliability.

Observations were made of 46 respondents and then the results were analyzed. Validation test used in this study was the face validity. The questionnaire was distributed to the selected 46 respondents and then the results were analyzed. The validation test used in this study was Pearson bivariate correlation test (Pearson Product Moment). Bivariate Pearson correlation test results obtained for each question item had a value of $r$ greater than $\mathrm{r}$ table (r: 0.202). Pearson bivariate correlation test criteria were: if $\mathrm{r}$ count $>\mathrm{r}$ table (2-sided test with sig.<0.05), then the instrument or question items correlated significantly to the total score (declared valid). Whereas, if the opposite then it was declared invalid. Accordingly, from the results of the validity test, all questions in the questionnaire were considered valid.

From the 25 HOME FAST instrument questions that were translated, there were 4 invalid questions. Accordingly, there were some changes to the questions numbered 11 , 12,13 , and 14 because the respondents tested had no use of bathtub, no shower cubicle and no slip resistant doormat on the floor of the bathroom. In addition, there was an adaptation with the Java language to facilitate the respondents to provide information.

\section{Table 1. Changes HOME FAST into HOME FAST adaptation}

\begin{tabular}{|c|c|c|}
\hline Question 11 & $\begin{array}{l}\text { Can the person get in and out of the bath easily and safely? } \\
\text { Definition: } \\
\text { One can step over the edge of the tub without risk, and can } \\
\text { lower themselves into the tub and get up again without } \\
\text { having to hold on to the furniture (or use a bathtub bowl, } \\
\text { or stand to use the shower without risk) }\end{array}$ & $\begin{array}{l}\text { Can the person use the bathtub easily and safely? - Ora } \\
\text { kangelan nyidhuk banyu? } \\
\text { Definition: } \\
\text { The tub height is more than } 50 \mathrm{~cm} \text {, no need to bend for } \\
\text { water from the bath. }\end{array}$ \\
\hline Ques & $\begin{array}{l}\text { Can the person walk in and out of the shower cubicle } \\
\text { easily and safely? } \\
\text { Definition: } \\
\text { One can step behind a shower door or reach the door rail } \\
\text { without risk and without having to hold anything. }\end{array}$ & $\begin{array}{l}\text { Can the person walk in and out of the bathroom or toilet } \\
\text { easily and safely? Gampang mlebu metu kamar mandi? } \\
\text { Definition: } \\
\text { One can step over the threshold of the bathroom door or } \\
\text { reach the door rail without risk and without having to } \\
\text { hold anything. }\end{array}$ \\
\hline Que & $\begin{array}{l}\text { Is there an easy-to-reach grip / holder in the shower room } \\
\text { or next to the bathtub? } \\
\text { Definition: } \\
\text { The grip is securely attached to the wall, which is not a } \\
\text { towel rack, and which can be reached without leaning } \\
\text { which results in a loss of balance. }\end{array}$ & $\begin{array}{l}\text { Is there an easy-to-reach grip/holder in the bathroom or } \\
\text { next to the toilet? Ono sik kanggo gocekan? } \\
\text { Definition: } \\
\text { Handles securely mounted against walls, which are not } \\
\text { towel rails, and which can be reached without leaning } \\
\text { which results in a loss of balance. }\end{array}$ \\
\hline Question 14 & $\begin{array}{l}\text { Is a slip resistant mat used in the bath/shower? } \\
\text { Definition: } \\
\text { Resilient slip-resistant rubber mats, on slipper stickers at } \\
\text { the bottom of the bath or shower cubicle. }\end{array}$ & $\begin{array}{l}\text { Is the bathroom floor slippery? Ora mleseti, garing, ora } \\
\text { lumuten? } \\
\text { Definition: } \\
\text { The bathroom floor is anti-slip, not cracked, with no } \\
\text { water pooled on the bathroom floor }\end{array}$ \\
\hline
\end{tabular}

After changing the questions number 11, 12, 13, and 14 and adding the Java language to facilitate communication the questionnaire was tested again on 30 respondents and got the valid result for all questions. Testing the reliability of this questionnaire by using the formula Cronbach Alpha obtained results $0.8461 \quad(>0.600)$. From these results, it can be concluded that the questionnaire is considered to be a valid and reliable instrument. 
40 Dewi Susilowardani et al. | Adaptation of Home Falls and Accidents Screening Tool (HOME FAST)... | Research Article

\section{RESULTS}

From the elderly data of the Puskesmas Loano with 11 villages, there were 1463 people \pm 65 years old age, and when stratified random sampling was done, there were 300 research subjects selected.

Table 2. Characteristics of research results

\begin{tabular}{|c|c|c|}
\hline Characteristics & Frequency & Percentage* \\
\hline \multicolumn{3}{|l|}{ Gender } \\
\hline Male & 135 & $45 \%$ \\
\hline Female & 165 & $55 \%$ \\
\hline \multicolumn{3}{|l|}{ Age } \\
\hline Average and SD & \multicolumn{2}{|c|}{73.4 years old (SD 6.88) } \\
\hline \multicolumn{3}{|l|}{ Occupation } \\
\hline Retired & 44 & $14.67 \%$ \\
\hline Farmers & 99 & $33 \%$ \\
\hline Entrepreneur & 30 & $10 \%$ \\
\hline Etc. & 127 & $42.33 \%$ \\
\hline \multicolumn{3}{|l|}{ Education Level } \\
\hline No School & 106 & $35.33 \%$ \\
\hline Elementary School & 124 & $41.33 \%$ \\
\hline Junior High School & 37 & $12.33 \%$ \\
\hline Senior High School & 20 & $6.67 \%$ \\
\hline College & 13 & $4.33 \%$ \\
\hline \multicolumn{3}{|l|}{ Type of Income } \\
\hline Permanent & 61 & $20.33 \%$ \\
\hline Not Fixed & 239 & $79.67 \%$ \\
\hline \multicolumn{3}{|l|}{ Marital Status } \\
\hline Married & 157 & $52.33 \%$ \\
\hline Married (widow/widower) & 143 & $47.67 \%$ \\
\hline \multicolumn{3}{|c|}{ Scoring HOME FAST Classification } \\
\hline Safe ( $\leq 14$ points $)$ & 110 & $36.66 \%$ \\
\hline Not Safe (>14 points) & 190 & $67.33 \%$ \\
\hline \multicolumn{3}{|l|}{ Fall Incident } \\
\hline Yes & 91 & $31.44 \%$ \\
\hline No & 209 & $69.66 \%$ \\
\hline
\end{tabular}

*amount divided by total research subjects; SD. Standard deviation

The results of the bivariate analysis in Table 3 show that there were three statistically related factors: sex, age and the total score from the HOME FAST adaptation questionnaire. Gender was statistically significantly associated with the incidence of falling $p=0.045$ (95\% CI 2.14-2.56) with RP 1.57 whereas age was significant with $p=0.046$ with $(95 \%$ CI 2.85-3.46), and Unsafe Risk of total scoring of HOME FAST adaptation with $p=0.024$. Furthermore, the other factors studied in this research including income type, marital status, education level and occupation were not statistically significant $(p>0.05)$ and had no significant correlation to fall incidence.

The scores in the HOME FAST adaptation questionnaire were scored with 0 for YES and 1 for NO. Then, the score of each question was summed and the total score analyzed for the area under curve (AUC). From result of the analysis of the Receiver Operating Characteristics (ROC) curve, the cutoff value from the sensitivity value adjusted with the specificity was 14 .

From the $2 \times 2$ table calculation, the sensitivity of HOMEFAST's adaptation score scheme was $46 \%$, meaning that $46 \%$ of patients' falling are categorized as having high risk of falling based on the current HOMEFAST adaptation scoring method. The scaling method for specificity was $67 \%$ meaning that $67 \%$ of healthy subjects are categorized as having no high risk of falling based on the current HOMEFAST adaptation scoring method.

\section{DISCUSSION}

Research on the prevalence of falling among the elderly in Indonesia has not been done. The results of this research show the prevalence of falling among respondents with age of $65-96$ years was $31.44 \%$. This finding is in line with WHO data which stated that more than one-third of the elderly suffer a fall every year ${ }^{1}$.

Gender was statistically significantly associated with fall incidence of $p=0.045$ (95\% CI 2.14-2.56) with RP 1.57 . This finding may be because women's life expectancy is higher than men, which is seen with the presence of more elderly female population than elderly men ${ }^{7}$. Data from the research subjects' characteristics showed that the proportion of female elderly was more than men, and this is in line with data in Indonesia where the highest life expectancy is among women and the elderly population is mostly women. The results of this study were also supported by research conducted by Bischoff et al. that reported that elderly women who are still able to walk have lower muscle strength and have a risk of falling more easily than older men who are still able to walk because the functional capacity of men is better than women ${ }^{8}$. 
Table 3. Results of statistical characteristics analysis

\begin{tabular}{|c|c|c|c|}
\hline Characteristics & Fall & Not Fall & Score $\mathrm{p}^{* *}$ \\
\hline \multicolumn{4}{|l|}{ Gender } \\
\hline Male & 33 & 102 & $p=0.045$ \\
\hline Female & 58 & 107 & $\mathrm{RP}=0.70 \mathrm{CI}=0.64-0.75$ \\
\hline \multicolumn{4}{|r|}{ te } \\
\hline Áverage and SD & \multicolumn{2}{|c|}{73,4 years (SD 6,88) } & $\begin{array}{l}p=0.043^{* *} \\
(\mathrm{CI}=-3.7--0.059)\end{array}$ \\
\hline \multicolumn{4}{|l|}{ Occupation } \\
\hline Retired & 11 & 33 & $p=0.156$ \\
\hline Farmers & 27 & 72 & \\
\hline Entrepreneur & 6 & 24 & \\
\hline Does not work & 47 & 80 & \\
\hline \multicolumn{4}{|l|}{ Level of education } \\
\hline No school & 35 & 71 & $p=0.274$ \\
\hline SD & 39 & 85 & \\
\hline SMP & 6 & 31 & \\
\hline SMA & 8 & 12 & \\
\hline College & 3 & 10 & \\
\hline \multicolumn{4}{|l|}{ Type of income } \\
\hline Permanent & 17 & 44 & $p=0.639$ \\
\hline Not fixed & 74 & 165 & $\mathrm{RP}=0.90 \mathrm{CI}=0.87-0.93$ \\
\hline \multicolumn{4}{|l|}{ Marital status } \\
\hline Mąried & 41 & 116 & $p=0.096$ \\
\hline married (widow / widower) & 50 & 93 & $\mathrm{RP}=0.75 \mathrm{CI}=0.70-0.80$ \\
\hline \multicolumn{4}{|c|}{ Scoring HOME FAST Classification } \\
\hline Safe ( $\leq 14$ points $)$ & 42 & 68 & $p=0.024$ \\
\hline Not Safe ( $>14$ points) & 49 & 141 & $\mathrm{RP}=1.48 \mathrm{CI}=1.39-1.58$ \\
\hline
\end{tabular}

$* * \mathrm{X}_{2}$ test compared to fall event $* * * \mathrm{t}$-test test

The age factor was also significantly associated with falling incidence with the value of $p=0.046$ (95\% CI: 2.85-3.46) The epidemiological data indicated that the incidence of falls was reported to occur in approximately $30 \%$ of people 65 years and older every year, and 40 to $50 \%$ of them are over 80 years old. One third of those aged 65 and older and living in a home (community) experience one fall every year, and about 1 in 40 people who fall require hospitalization. Falls among the elderly resulted in two thirds of all accidental deaths ${ }^{9}$.

Table 4. Diagnostic test adapted HOMEFAST scoring method

\begin{tabular}{lccc}
\hline Scoring System & \multicolumn{2}{c}{ Fall } & Total \\
\cline { 2 - 4 } HOME FAST & Yes & No \\
\hline Fall & 42 & 68 & 110 \\
Not Fall & 49 & 141 & 190 \\
\hline Total & 91 & 209 & 300 \\
\hline Sn $=46 \% ; \mathrm{Sp}=67 \% ;$ & $\mathrm{NRP}=38 \% ; \mathrm{NRN}=74 \%$ \\
\multicolumn{4}{c}{ LR+ $=1.42 ; \mathrm{LR}-=0.80$}
\end{tabular}

There is a significant correlation between falling incidence in elderly with family social and economic characteristics ${ }^{10}$.

The percentage of falls in the elderly who live alone (28.6\%) is greater than the elderly who live with their family $(14 \%)^{11}$. Living alone is the main factor related to the incidence of falling in the elderly ${ }^{12}$.

Insecure risk classification of total HOME FAST adaptation scores $(p=0.024, p<0.05)$ was significantly correlated with fall incidence. In the literature review, it shows an age-old interaction with the environment and falls. However, there have been no reports of environmental ties with falling risks ${ }^{13}$. Most of the occurrences of falls occur in homes and surrounding environments. The assessment of falling risk factors including hazards in the home environment is important for preventing falls and injuries in old age ${ }^{14}$.
The results of HOME FAST adaptation study of the most unsafe group of floor conditions (P1, P2, P3, P4) were the floor mats (P4), where mats were not securely installed in as much as $186(62 \%)$ homes, while those with safely installed mats were $114(32 \%)$. This is in line with the HOME FAST research in China that says the floor surface is in good condition, almost $20 \%$ of the floors are slippery, and more than $40 \%$ of respondents say the mat is not securely installed on the floor ${ }^{15}$.

The most unsafe furniture group (P5, P6) involves waking up from a lounge chair (P6), which is not a safe chair because the lounge chairs do not have a sturdy grip or arm supports in as many as $102(34 \%)$ homes, while those which are safe include as much as $198(66 \%)$. This is in line with HOME FAST research in China where most respondents reported that their lounge chairs do not have a handle. Respondents mentioned that their furniture has been used for more than 25 years, and the condition of this old furniture should be realized by the elderly ${ }^{15}$.

The most insecure lighting group factor (P7, P8) was not light enough to see clearly (P7), that is it was not bright enough to see clearly in as much as $126(42 \%)$ homes. This is in line with HOME FAST research in China, which found that when waking up at night, more than half of respondents reported that they rarely turn on the lights from the bed, because the switch is too far away, and most respondents reporting that they cannot reach and light up their lights from the bed easily. "The lighting" condition is an important concern to prevent the risk of falls ${ }^{15}$. In addition, no respondents reported the lights being turned on during the night ${ }^{15}$.

The most unsafe group factor of bathrooms and toilets (P10, P11, P12, P13, P14, P15) involves the distance of a 
toilet with the bedroom (P15). Some elderly people do not have toilets in the house, and they use the neighbor's toilet or they defecate in the pond or yard. In most of the elderly houses, the distance of the toilet from the bedroom was far (more than 2 doors) in as much as $230(76.67 \%)$ homes. This is different from the HOME FAST research in China, conducted by Lai et al. that reported about $1 / 3$ of respondents could easily walk out and enter the toilet from their shower cubicle. However, most reported that there was no proper handrail grip, and they relied on their water /sink pipes to get a resting place if they needed help. Some (about 10\%) respondents (mostly villagers) reported that they were still using the squat toilets, and some (less than $5 \%$ ) even visited the public toilets for urinary use $\mathrm{e}^{15}$.

From the kitchen group (P16, P17), the most unsafe aspect was to grab things in the kitchen easily without a foothold on chairs or blocking furniture and with no kitchen fixtures on the floor. The unsafe score for P16 was in 202 (67.33\%) homes. As reported in a study in Turkey using the Evaluation Form of Domestic Environmental Risk Factors of Falling (EFDERF), the kitchen area is the second most common place with furniture that caused the falling incidence ${ }^{16}$.

From unsafe footwear groups because of using inappropriate sandals, sandals which are not anti-slip or respondents do not wear appropriate home sandals were in as much as $174(58 \%)$ homes. One study found that more than $25 \%$ of elderly did not wear appropriate shoes or slippers in the house. Walking barefoot or just wearing socks increases the risk of falling home ${ }^{1}$.

Besides using HOME FAST, safety checks can also use CDC Check Safety, and the Home Safety Self-Assessment Tool (HSSAT).

\section{CONCLUSIONS}

From this study, it is concluded that the HOME FAST adaptation cannot be used to screen for extrinsic fall risks in elderly in Purworejo District first-level health facilities because the sensitivity is low. The prevalence of HOME FAST adaptation results in risks of falling was $36.66 \%$, with the number of safe houses reaching 190 housing units, and 110 unsafe home units.

Prevalence of falling was $31.4 \%$ in the study population. The components of elderly homes that are most unsafe from the results of the research are: (1) Unsafe Floor: doormat mounted unsafe on the floor; (2) Unsafe Furniture: Relaxing chair without a handle and not sturdy, outdated;

(3) Unsafe Illumination: cannot see clearly and not bright enough at night; (4) Unsafe Bathroom and toilet: the distance between the bedroom and toilet is more than 2 doors; and (5) Unsafe Kitchen area: kitchen utensils on the floor so they need to bend over to reach it.

Further research needs to be conducted with the cohort method and sufficient time to be able to see and follow the research directly. Also, home visits need to be made to assess risk factors for falling especially in homes of elderly people living alone with HOME FAST adaptation instruments. Additional research is needed because the validation in this study only used face validity, by consulting with expert panels, while with internal and external validation of the HOME FAST adaptation instrument, it is expected that the adaptation of the HOME FAST instrument would become more sensitive.

\section{Acknowledgments}

Our greatest thanks go to Prof. dr. Hari Kusnanto J. SU. DrPH and Dr. dr. Djayanti Sari, M Kes. Sp. An-KAP. We also want to thank the friends of the research team at the Puskesmas Loano who have been very helpful in this research. Many thanks to the respondents for the validation and the research subject who took their time for the observations and interviews in this research.

\section{Ethical Approval and Informed Consent}

This research has been approved by Medical and Health Research Ethics Committee (MHREC) from the Faculty of Medicine, Public Health, and Nursing, Universitas Gadjah Mada with reference number KE/FK/1315/EC/2017.

\section{Funding}

\section{Availability of Data and Material}

Data and material can be accessed via corresponding author.

\section{Conflict of Interest}

The researchers did not have a conflict of interest in this study.

\section{REFERENCES}

1. World Health Organization. WHO Global Report on Falls Prevention in Older Age. Geneva: World Health Organization; 2007. Available from: https://www.who.int/ageing/publications/Falls_ prevention7March.pdf

2. Romli MH, Mackenzie L, Lovarini M, Tan MP. Pilot study to investigate the feasibility of the home falls and accidents screening tool (HOME FAST) to identify older Malaysian people at risk of falls. BMJ Open 2016; 6(8): e012048.

3. Handayani A. Prevalence and distribution of systemic intrinsic risk factors that affect postural instability in geriatric patients in the geriatric division of the department of disease in RSUPN Jakarta General Hospital [Thesis]. Jakarta: Universitas Indonesia; 2003.

4. District Executive Unit. SESLHD Falls Injury Prevention Plan 20132018. New South Wales: South Eastern Sydney Local Health District; 2013 [Update Feb 2014]. Available from: https://www.seslhd.health. nsw.gov.au/sites/default/files/groups/Planning_Population_and_ Equity/Health_Plans/SESLHDfallsinjplanupdateFeb2014.pdf

5. Central Statistics Agency of Purworejo Regency. Population of Purworejo Regency projection result from 2010-2020. Purworejo: Central Statistics Agency of Purworejo Regency; 2016.

6. Mackenzie L, Byles J, Higginbotham N. Designing the Home Falls and Accidents Screening Tool (HOME FAST): selecting the items. British Journal of Occupational Therapy. 2000; 63(6): 260-69.

7. Ministry of Health Republic of Indonesia. Ministry of Health regulation number 25 of 2016 regarding the national health plan for the elderly in 2016-2019. Republic of Indonesia Public Letter of 2016

Number 1091. Jakarta: Ministry of Health Republic of Indonesia; 2016.

8. Bischoff HA, Stähelin HB, Monsch AU, Iversen MD, Weyh A, von Dechend M, Akos R, Conzelmann M, Dick W, Theiler R. Identifying a cut-off point for normal mobility: a comparison of the timed 'up and go' test in community-dwelling and institutionalized elderly women. Age Ageing. 2003 May; 32(3): 315-20.

9. Tinetti ME, Speechley M, Ginter SF. Risk factors for falls among elderly persons living in the community. New England Journal of Medicine. 1988; 319(26): 1701-7.

10. Topac S, Ateskan U, Ceylan S, Bicer T. Analysis of various characteristics of home accidents in elderly under routine monitoring in hospital for medical education. Gillhame Military Medical Academy. 2004. 
11. Lee WJ, Cheng YY, Liu JY, Yang KC, Jeng SY. Living alone as a red flag sign of falls among older people in rural Taiwan. Journal of Clinical Gerontology \& Geriatrics. 2011; 2(3): 76-9.

12. Yeong UY, Tan SY, Choo WY. Prevalence of falls among communitydwelling elderly and its associated factors: a cross-sectional study in Perak, Malaysia. Malays Fam Physician. 2016; 11(1): 7-14.

13. Leiva-Caro JA, Salazar-Gonzáles BC, Gallegos-Cabriales EC, Gómez-Meza MV, Hunter KF. Connection between competence, usability, environment and risk of falls in elderly adults. Rev. Latino-Am. Enfermagem. 2015; 23(6): 1139-48.

14. Hefny AF, Abbas AK, Abu-Zidan FM. Geriatric fall-related injuries. African Health Sciences. 2016; 16(2): 554-9.

15. Lai FHY, Louie SWS, Poon CMY, Wong GLH, Wong SKM. Evaluate the effectiveness of a home safety screening tool to assess fall risk at home for elderly with fragility fracture: validation and application of the Chinese HOME Falls and Accidents Screening Tool (the Chinese HOME FAST). Hong Kong: Occupational Therapy Department, Tai Po Hospital; 2004. Available from: http://www3.ha.org.hk/ haconvention/hac2008/proceedings/pdf/Free\%20Paper/SPP2-2.pdf

16. Lök N, Akin B. Domestic environmental risk factors associated with falling in elderly. Iranian J Publ Health. 2013; 42(2): 120-8.

\section{ATTACHMENT}

\begin{tabular}{lcc}
\hline HOME FAST Adaptation & YES & NO \\
\hline
\end{tabular}

Definition: Home refers to the outside and inside of one's occupancy property. Since checklists will be used for daylight visits, answers need to take into account the same home atmosphere at night.

\section{FLOOR}

1. Does the place run free of wires and other messy goods? Ora nyrimpeti?

Definition:

No cables or cluttered items (e.g. boxes, newspapers, objects) across or bothering

walking/exit and entry.

Including furniture and other items that blocked the entrance-entrance, or the hallway, the

stuff behind the door that blocked the door to open fully, the doorway raised at the entrance-entrance.

2. Is the floor in good condition? Ora kejeglong?

Definition:

No cracked or missing tiles, flat floor.

3. Is the floor surface anti-slip? Ora mleseti? Definition:

Rate "no" if the floor or tile in your room, room, kitchen, bathroom or laundry area is slippery (easy to slip).

4. Are the mats securely mounted on the floor? Ora nyandhungi? Definition:

Mats made of anti-slip material, have a good slip resistant bottom/plastered or nailed to the floor.

\section{FURNITURE}

5. Can people get up and down from bed easily and safely? Ora kangelan tangi? Ora kangelan tangi?

Definition:

Beds have adequate height and robustness. People do not have to climb to the furniture beside the bed. The bed is not too low making it difficult to get up.

6. Can the person get up from the easy chair and secure? Ora kangelan tangi?

Definition:

The seat has a sufficient height, armrest can be reached to push yourself up, seat cushion is not too soft or thick. The seat is made of sturdy material.

\section{LIGHTING}

7. Are all lights bright enough so that the person can see clearly? Padhang iso jelas namatke?

Definition:

Is the room bright enough (painted in bright colors without curtains with tightly woven material)?

8. Can the person light the lamp easily from the bed? Ora grayangan?

Definition:

The switch is in the room, easy to reach - has a flashlight or lights or a flashlight on the side of the mattress, using the night lights in the hallway.

\section{HOME ACCESS}

9. Are the walkways, steps and entrances outside bright enough at night? Padhang iso namatke? Definition: 
44 Dewi Susilowardani et al. | Adaptation of Home Falls and Accidents Screening Tool (HOME FAST)... | Research Article

The lights are on the back and front doors. Is the main place used exposed to light including the shared lobby? Are they painted in bright colors?

\section{BATHROOM AND TOILET}

10. Does the person get up and down the toilet easily and safely? Ora kangelan nganggo closet? Definition:

Toilets have adequate altitude, one does not have to hold on to the sink / towel rail / where the tissue rolls to get up, the handle is next to the toilet, if necessary.

11. Can the person use the bathtub easily and safely? Ora kangelan nyidhuk banyu? Definition:

The tub height is more than $50 \mathrm{~cm}$, no need to bend for water from the bath.

12. Can the person walk in and out of the bathroom or toilet easily and safely?

Gampang mlebu metu kamar mandi?

Definition:

A person can access bathroom door, with a rail in hallway, and it must have a handgrip.

13. Is there an easy-to-reach grip/holder in the bathroom or toilet? Ono sik kanggo gocekan? Definition:

The handles are mounted to a wall, which is not a towel holder, and a balancer is not a leaning one which results in a loss of balance.

14. Is the bathroom floor antislip? Ora mleseti, garing, ora lumuten?

Definition:

The bathroom floor is anti-slip, with no water pooled in the bathroom floor.

15. Are the toilets close to the bedroom? Cedak kamar turu?

Definition:

No more than 2 doors away (including bedroom door) - does not include going out or opening the door to get there.

\section{KITCHEN}

16. Can the person easily reach for items in the kitchen used regularly without climbing, bending or disturbing his balance? Dapur rapi, ora mbungkuk njupuk perkakas dapur? Definition:

The furniture in the kitchen is easy to pick up, no need to rest on furniture to pick up, the furniture in the kitchen is not located on the ground so no need to bend and the furniture does not block the walk.

17. Can the person carry food easily and safely from the kitchen to the dining room? Ora nyandhungi?

Definition:

Food can be carried safely by walking from the kitchen free of messy goods and flat floors.

\section{LOAD STAIRS AND FLOORS}

18. Is the floor uneven or the stairs inside the house easy to navigate? Trap ora nyandhungi? Definition:

Uneven floors or steps connecting between spaces are easy to traverse, with clear borders, and not cracked.

19. Is it easy for a person to get a sturdy hold (row) place to go through an uneven floor or stairs? Iso gocekan?

Definition:

The holding area is easy to reach, firmly mounted, strong enough and reaches the entire step.

20. Can the person easily climb up and down stairs, both outside and inside the house?

Trap ora dhuwur tur ombo?

Definition:

The stairs are not too tall, too narrow or too uneven for the feet to climb to the step steadily (inside or outside the house), and people do not become tired or panting when using stairs/ ladders.

21. Can the edge of stairs be easily to be seen? Gampang kesawang?

Definition:

Not covering on the floor, no patterned tile or wall that can blur the edge of the stairs.

\section{DOOR}

22. Can the person use the entrance safely and easily? Ono papan ngadek sik cukup? Definition:

The keylock of the key can be reached without tiptoe, and there is a standing place so that the person does not have to balance household to open the door and/or the door screen. 
23. Are the walkways around the house in good condition, and free of clutter? Dalane setapak padhang, resik, rapi, semeblak?

Definition:

There were no cracking/rocking roads, lush plants/weeds, hanging trees, garden hoses blocking the pathway.

\section{FOOTWEAR}

24. Does the person wear the right slippers and shoes? Sandhal utawa sepatu pas?

Definition:

The person is wearing the right shoes and no heels, with a low sole and an anti-slip traction, or proper slippers that support the foot in a good position.

\section{PET}

25. If there is a pet, can the person take care of it without bending and risk falling? Iso ngopeni kewan kanthi gampang, ora ngeselke?

Definition:

Pets are any animal that the person is responsible for. The person does not need to feed the pet when the pet is jumping or is under, the person does not need to bend to the floor without a buffer to feed or clean the pet, the pet does not require much physical activity. 